\title{
Phytochemical and Antimicrobial Screening of Cola gigantea Leaves, Stem and Bark
}

\author{
Adindu Chukwuemeka Steve ${ }^{1}$, Odili Lucy Chidinma ${ }^{1}$, Nwagu Ezinne Emmanuella ${ }^{1}$, \\ Agu Kingsley Chukwuebuka ${ }^{2, *}$, Awah Nsikak Sunday ${ }^{2}$, Okeke Benjamin Chidi ${ }^{2}$, Orjionwe Rita Nchedo ${ }^{3}$ \\ ${ }^{1}$ Department of Applied Biochemistry, Nnamdi Azikiwe University, PMB 5025, Awka, Nigeria \\ ${ }^{2}$ Department of Applied Microbiology and Brewing, Nnamdi Azikiwe University, PMB 5025, Awka, Nigeria \\ ${ }^{3}$ GeoSearch Inc. Calgary, Canada
}

Copyright $\bigcirc 2016$ by authors, all rights reserved. Authors agree that this article remains permanently open access under the terms of the Creative Commons Attribution License 4.0 International License

\begin{abstract}
Phytochemical and antimicrobial analysis were carried out on the leaves, stem and bark extracts of Cola gigantea. The Phytochemicals present in the plant were Flavonoid, Tannins, Alkaloid, Cardiac glycoside, Steroids, Terpenoids and phenol. Flavonoid, Alkaloid and steroids were present in high amount in the plant than the other phytochemicals. For antimicrobial screening, the well-in-agar diffusion method was employed and the various zones of inhibition produced by the extract of the various plant parts on Escherichia coli, Bacillus subtilis, Staphylococcus aureus and Candida albicans were observed and recorded in millimeters $(\mathrm{mm})$. The leaves of the plant had highest antimicrobial activities on Escherichia coli, Bacillus subtilis and Staphylococcus aureus, while the stem had highest antimicrobial activity on Candida albicans. The observed antimicrobial activity of the extract suggests its potential use in the treatment of diseases produced by the various test pathogenic microorganisms.
\end{abstract}

Keywords Phytochemistry, Antimicrobial Screening, Cola gigantea, Leaf, Stem, Bark

\section{Introduction}

The use of traditional remedies in West-Africa in the treatment of diseases has witnessed a flourishing patronage. This has been influenced both by the development of resistance by pathogenic microorganisms [Tenover, 2006] and by the ready availability of potential plants in the West-African forests. Plants contain a plethora of bioactive substances that could be antispasmodic, emetic, anti-cancer and antimicrobial in nature [Frank and Kingsley, 2014]; [Okigbo et al., 2015]. A large number of the plants are claimed to possess the antibiotic properties in the traditional system and are also used extensively by the tribal people worldwide. It is now believed that nature has given the cure of every disease in one way or another [Tiwari et al., 2011]. Seeking a better and more cost effective means in the treatment and management of diseases, man has continually utilized the resources in his immediate environment.

Cola gigantea belongs to Sterculiaceae family and grows as a large forest tree. It is found both in the relatively dry and wet parts of the rain forest. It is an ever green moderately sized tree often growing to a height of 20-25metres with an erect trunk of about 1.5 metres of diameter and possessing a vertically fissured grey or brown bark. It is erect, non-cylindrical and bearing a dense spreading crown with glossy ovoid leaves up to $20 \mathrm{~cm}$ [Irvine, 1961]. This specie is native to Western Tropical Africa where it is predominantly found in the Savannahs and semi-deciduous forests.

Cola gigantea is one of the plants utilized in traditional healing remedies [Sonibare et al., 2009]. The characteristic bitter taste of its fruit makes it a favorite amongst the elderly as it is widely used in social and cultural events to welcome guests and say traditional prayers. It is also known to reduce hunger pangs. Several other parts of the plant such as the leaves, bark and fruits are utilized in traditional healing remedies. The fruits when ingested acts as a stimulant, creating an ecstatic and euphoric state [Benjamin et al., 1991]. It is also used traditionally to treat whooping cough, malaria, depression, anxiety and sea-sickness [Odugbem, 2006], [Muthu et al., 2006]. A study by [Christian et al., 2012] shows that the ethanolic extracts of the stem bark and leaves of cola gigantea exhibit anti-inflammatory properties in carrageenan induced arthritis in seven-day old chicks and anti-microbial properties against strains of E.coli, $P$. aeruginosa, $S$. aureus and $B$. subtilis.

This work was aimed at determining the phytochemicals present in the leaf, stem and bark of cola gigantean and the anti-microbial properties of various extracts of the plant parts on the micro-organisms Candida albicans, Bacillus subtilis, Staphylococcus aureus, and Escherichia coli. 


\section{Materials and Methods}

\section{Plant Collection and Identification}

Cola gigantea leaves, stem and bark were collected from an uncultivated farmland located at Agwa in Oguta Local Government Area of Imo State. The plant was identified at the Department of Botany, Nnamdi Azikiwe University, Awka, Anambra State, Nigeria.

\section{Sample Preparation}

The leaves, stem and bark of the plant were washed with tap water to remove debris and air dried for two weeks. Grinding of the plant parts was carried out using a manual grinder and then an electric blender to obtain a fine powder.

Preparation of Aqueous Extracts: To $50 \mathrm{~g}$ each of the blended plant parts, $1000 \mathrm{ml}$ of distilled water was added. The samples were kept for 72 hours at room temperature with stirring at regular intervals. After the 72 hour incubation, the samples were filtered using Whatmann No. 1 filter paper and the filtrate was kept for analysis. (Tasmin et al., 2015).

Preparation of Ethanol and Hexane Extracts: $2 \mathrm{~kg}$ each of the blended plant parts were dissolved in absolute ethanol (98\%) and another $2 \mathrm{~kg}$ each of the blended parts were dissolved in hexane $(96 \%)$. They were incubated for 72 hours and filtered at the end of the incubation period using Whatmann No. 1 filter paper. The filtrate was kept for analysis. (Sayed et al., 2012).

\section{Phytochemical Screening Tests}

Chemical tests were carried out on the extract using standard procedures to identify the constituents as described by Sofowara (1993), Trease and Evans (1989) and Harborne (1973).

\section{Qualitative Analysis}

\section{Test for Flavonoids}

$5 \mathrm{ml}$ of dilute ammonia solution were added to a portion of the aqueous filtrate of each plant extract followed by addition of concentrated $\mathrm{H}_{2} \mathrm{SO}_{4}$. A yellow colouration observed in each extract indicated the presence of flavonoids. The yellow colouration disappeared on standing.

\section{Test for Tannins}

About $0.5 \mathrm{~g}$ of the dried powdered samples was boiled in $20 \mathrm{ml}$ of water in a test tube and then filtered. A few drops of $0.1 \%$ ferric chloride was added and observed for brownish green or a blue-black colouration.

\section{Test for Saponin}

About $2 \mathrm{~g}$ of the powdered sample was boiled in $20 \mathrm{ml}$ of distilled water in a water bath and filtered. $10 \mathrm{ml}$ of the filtrate was mixed with $5 \mathrm{ml}$ of distilled water and shaken vigorously for a stable persistent froth. The frothing was mixed with 3 drops of olive oil and shaken vigorously, then observed for the formation of emulsion. (Harborne 1973).

\section{Test for Alkaloids}

To the hexane extract of the plant sample $5 \mathrm{ml}$ of $2 \% \mathrm{HCl}$ was added. The mixture was heated, filtered and a few drops of picric acid were poured into it. Formation of yellow colour precipitate indicates the presence of alkaloids.

\section{Test for Terpenoids}

$5 \mathrm{ml}$ of plant extract is mixed in $2 \mathrm{ml}$ of chloroform and $3 \mathrm{ml}$ of concentrated $\mathrm{H}_{2} \mathrm{SO}_{4}$ is carefully added to form a layer. Reddish brown interface formed shows presence of terpenoids.

\section{Test for Steroids}

$2 \mathrm{ml}$ of acetic anhydride is added to $0.5 \mathrm{~g}$ of ethanolic extract of each sample with $2 \mathrm{ml}$ of $\mathrm{H}_{2} \mathrm{SO}_{4}$. Colour change from violet to blue or green indicates presence of steroids.

Test for cardiac glycosides (Keller-Killani test): Five $\mathrm{ml}$ of each extracts was treated with $2 \mathrm{ml}$ of glacial acetic acid containing one drop of ferric chloride solution. This was underlayed with $1 \mathrm{ml}$ of concentrated sulphuric acid. A brown ring of the interface indicates a deoxysugar characteristic of cardenolides. A violet ring may appear below the brown ring, while in the acetic acid layer, a greenish ring may form just gradually throughout thin layer.

\section{Quantitative Analysis}

Alkaloid determination using Harborne (1973) method: $5 \mathrm{~g}$ of the sample was weighed into a $250 \mathrm{ml}$ beaker and $200 \mathrm{ml}$ of $10 \%$ acetic acid in ethanol was added and covered and allowed to stand for $4 \mathrm{~h}$. This was filtered and the extract was concentrated on a waterbath to one-quarter of the original volume. Concentrated ammonium hydroxide was added dropwise to the extract until the precipitation was complete. The whole solution was allowed to settle and the precipitated was collected and washed with dilute ammonium hydroxide and then filtered. The residue is the alkaloid, which was dried and weighed.

Flavonoid determination by the method of Bohm and Kocipai - Abyazan (1994): $10 \mathrm{~g}$ of the plant sample was extracted repeatedly with $100 \mathrm{ml}$ of $80 \%$ aqueous methanol at room temperature. The whole solution was filtered through whatman filter paper No $42(125 \mathrm{~mm})$. The filtrate was later transferred into a crucible and evaporated into dryness over a water bath and weighed to a constant weight.

\section{Cardiac Glycoside Determination}

To $1 \mathrm{ml}$ of the water extract of each sample was added $1 \mathrm{ml}$ of $2 \%$ solution of 3,5 -DNS (Di-nitro Salicylic acid) in 
methanol and $1 \mathrm{ml}$ of $5 \%$ aqueous $\mathrm{NaOH}$. It was boiled for 2 mins (until brick-red precipitate was observed) and the boiled sample was filtered. The weight of the filter paper was taken before filtration. The filter paper with the absorbed residue was dried in an oven at $50{ }^{0} \mathrm{C}$ till dryness and weighed.

\section{Tannin Determination}

$20 \mathrm{~g}$ of powdered sample was put in a conical flask and $100 \mathrm{ml}$ of petroleum ether was added and covered for 24hours. The sample was then filtered and allowed to stand for 15 minutes allowing petroleum ether to evaporate. It was then re-extracted by soaking in $100 \mathrm{ml}$ of $10 \%$ acetic acid in ethanol for 4 hours. The sample was then filtered and the filtrate collected. $25 \mathrm{ml}$ of $\mathrm{NH}_{4} \mathrm{OH}$ was added to the filtrate to precipitate the alkaloids. The alkaloids were heated with electric plate to remove some of the $\mathrm{NH}_{4} \mathrm{OH}$ still in solution. The remaining volume was measured to be $33 \mathrm{ml}$. [Pearson, $1974]$.

$5 \mathrm{ml}$ of this was taken and $20 \mathrm{ml}$ of ethanol was added to it. It was titrated with $0.1 \mathrm{MNaOH}$ using phenolphthalein as indicator until a pink end point is reached.

\section{Determination of Total Phenols by Spectrophotometric Method}

The quantity of phenol is determined using the spectrometer method. The plant sample is boiled with $50 \mathrm{ml}$ of butan-1-ol for 15 minutes. $5 \mathrm{ml}$ of the boiled sample is pipetted into a $50 \mathrm{ml}$ flask, and $10 \mathrm{ml}$ of distilled water is added. After the addition of distilled water, $2 \mathrm{ml}$ of $\mathrm{NH}_{4} \mathrm{OH}$ solution and $5 \mathrm{ml}$ of concentrated propanol is added to the mixture. The sample is made up to the mark and left for 30 minutes to react for colour development and measured at $505 \mathrm{~nm}$ wavelength using spectrometer.

\section{Determination of Steroids}

$1.0 \mathrm{~g}$ of powdered sample was weighed and mixed in $100 \mathrm{ml}$ of distilled water in a conical flask. The mixture was filtered and the filtrate eluted with $0.1 \mathrm{~N}$ ammonium hydroxide solution. $2 \mathrm{ml}$ of the eluent was put in a test tube and mixed with $2 \mathrm{ml}$ of chloroform. $3 \mathrm{ml}$ of ice cold acetic anhydride was added to the mixture in test tube.

\section{Determination of Terpenoid Content}

$1.0 \mathrm{~g}$ of powdered sample was weighed and mixed in $100 \mathrm{ml}$ of distilled water in a conical flask. The mixture was filtered and the filtrate eluted with $0.1 \mathrm{~N}$ ammonium hydroxide solution. $2 \mathrm{ml}$ of the eluent was put in a test tube and mixed with $2 \mathrm{ml}$ of chloroform. $3 \mathrm{ml}$ of ice cold acetic anhydride was added to the mixture in test tube.

\section{Test Organisms}

A total of three pathogenic bacteria namely: Escherichia coli, Staphylococcus aureus, Bacillus subtilis and one fungus, Candida albicans were obtained from the Medical
Laboratory section of Nnamdi Azikiwe University Teaching Hospital, Anambra State, Nigeria.

\section{Antimicrobial Susceptibility Test}

Agar well diffusion method was used to assay the effect of the extract on the various microorganisms. Mueller-Hinton agar was used for the bacteria and Sabouraud's Dextrose Agar (SDA) for the fungus. Twenty four hour broth cultures of the test organisms were serially diluted, then $10^{-3}$ and $10^{-4}$ dilution of each microorganism was uniformly spread using a sterile glass spreader on the surface of the media, and two wells were borne on each petri dish. Thereafter, $0.1 \mathrm{ml}$ of n-hexane and water extracts of each sample was added in the well on the petri dish. Incubation was done at $37{ }^{\circ} \mathrm{C}$ for 24 hours and clear zones of inhibition around the wells indicated antimicrobial activities of the extracts against the test organisms. The diameter of the zone of inhibitions were measured and recorded in millimeter. All experiments were done in duplicates.

\section{Results of the Phytochemical Screening}

\section{Qualitative Analysis}

\section{Leaves}

Table 1. Result of qualitative phytochemical screening on the leaves of Cola gigantea.

\begin{tabular}{|c|c|c|}
\hline TEST & OBSERVATION & INFERENCE \\
\hline Alkaloid & Precipitation present & + \\
\hline Saponins & Froth absent & - \\
\hline Flavonoid & Yellow colouration present & ++ \\
\hline Tannins & Brownish green colouration & + \\
\hline Steroids & Colour change from violet to blue & + \\
\hline Terpenoids & Presence of Reddish-brown layer. & + \\
\hline
\end{tabular}

\section{Stem}

Table 2. Result of qualitative phytochemical screening on the stem of Cola gigantea.

\begin{tabular}{|c|c|c|}
\hline TEST & OBSERVATION & INFERENCE \\
\hline Alkaloid & Precipitation present & + \\
\hline Saponins & No froth formed & - \\
\hline Flavonoid & Yellow colouration present & ++ \\
\hline Tannins & No colouration & - \\
\hline Steroids & Colour change from violet to green & + \\
\hline Terpenoids & Absence of Reddish-brown layer. & - \\
\hline
\end{tabular}


Bark

Table 3. Result of qualitative phytochemical screening on the Bark of Cola gigantea.

\begin{tabular}{|c|c|c|}
\hline TEST & OBSERVATION & INFERENCE \\
\hline Alkaloid & Precipitation present & + \\
\hline Saponins & Froth present & ++ \\
\hline Flavonoid & Yellow colouration present & ++ \\
\hline Tannins & No colouration & - \\
\hline Steroids & Colour change from violet to green & + \\
\hline Terpenoids & Absence of Reddish-brown layer. & - \\
\hline
\end{tabular}

\section{Key}

\begin{tabular}{|c|c|c|}
\hline S/No & Symbol & Meaning \\
\hline 1. & + & Indicated \\
\hline 2. & ++ & Strongly Indicated \\
\hline 3. & - & Not Indicated \\
\hline
\end{tabular}

\section{Quantitative Analysis}

\section{Leaves}

Table 4. Results of quantitative phytochemical screening of Cola gigantea.

\begin{tabular}{|c|c|}
\hline TEST & QUANTITY g/100g \\
\hline Alkaloid & 5.8 \\
\hline Flavonoid & 12.6 \\
\hline Tannins & 9.08 \\
\hline Steroids & 17.26 \\
\hline Terpenoids & 5.209 \\
\hline Phenol & 27.98 \\
\hline Cardiac glycoside & 2.2 \\
\hline
\end{tabular}

Stem

Table 5. Result of quantitative phytochemical screening on the stem of Cola gigantea.

\begin{tabular}{|c|c|}
\hline TEST & QUANTITY $\mathbf{g} / \mathbf{1 0 0 g}$ \\
\hline Alkaloid & 7.3 \\
\hline Flavonoid & 10.4 \\
\hline Tannins & 0.15 \\
\hline Steroids & 8.14 \\
\hline Terpenoids & 1.01 \\
\hline Phenol & 12.21 \\
\hline Cardiac glycoside & 1.4 \\
\hline
\end{tabular}

\section{Bark}

Table 6. Result of qualitative phytochemical screening on the bark of Cola gigantea.

\begin{tabular}{|c|c|}
\hline TEST & QUANTITY $\mathbf{g} / \mathbf{1 0 0 g}$ \\
\hline Alkaloid & 3 \\
\hline Flavonoid & 5.4 \\
\hline Tannins & 0.106 \\
\hline Steroids & 6.34 \\
\hline Terpenoids & 1.02 \\
\hline Phenol & 10.88 \\
\hline Cardiac glycoside & 2.3 \\
\hline
\end{tabular}

Table 7. Mean Viable Microbial Count (CFU/ml)

\begin{tabular}{|c|c|}
\hline Microorganisms & Mean Total microbial count cfu/ml \\
\hline Bacillus subtils & $2.54 \times 10^{7}$ \\
\hline Staphylococcus aureus & $2.66 \times 10^{7}$ \\
\hline Escherichia coli & $2.48 \times 10^{7}$ \\
\hline Candida albicans & $2.60 \times 10^{8}$ \\
\hline
\end{tabular}

Table 8. Microorganism's Mean Zone of Inhibition

\begin{tabular}{|c|c|c|c|}
\hline \multirow{2}{*}{ Microorganisms } & \multicolumn{2}{|c|}{ Zones of inhibition in mm (mean \pm SD) } \\
\hline Bacillus subtils & Cola gigantea leaves & Cola giganteastem & Cola gigantea bark \\
\hline Staphylococcus aureus & $18.00 \pm 1.67$ & $4.50 \pm 1.45$ & $23.00 \pm 1.18$ \\
\hline Escherichia coli & $23.50 \pm 1.45$ & $20.50 \pm 0.84$ & $11.00 \pm 1.18$ \\
\hline Candida albicans & $18.00 \pm 2.05$ & $14.00 \pm 1.18$ & $8.50 \pm 0.83$ \\
\hline
\end{tabular}




\section{Discussion}

The results of the phytochemical screening of the ethanolic extracts of the leaves, stem and bark of Cola gigantean showed very high levels of phenol in all samples. The leaves recorded the highest phenol levels of $27.98 \mathrm{~g} / 100 \mathrm{~g}$ with lowest levels of phytochemicals observed in cardiac glycosides with a value of $2.2 \mathrm{~g} / 100 \mathrm{~g}$. Phenol levels of $12.21 \mathrm{~g} / 100 \mathrm{~g}$ and $10.88 \mathrm{~g} / 100 \mathrm{~g}$ were observed for the stem and bark respectively. Both the stem and bark recorded the lowest levels of the phytochemical tannin with values of $0.15 \mathrm{~g} / 100 \mathrm{~g}$ and $0.106 \mathrm{~g} / 100 \mathrm{~g}$ respectively. This is in line with the work by [Christian et al., 2012] which revealed the presence of tannins, saponins, alkaloids and steroids in the leaves and stem bark of Cola gigantea.

The plant was tested for antimicrobial activities against a number of selected microorganisms viz. Escherichia coli, Bacillus subtilis, Staphylococcus aureus and Candida albicans. The aqueous extracts of the plant had no activity on the microorganisms used because water is polar in nature. The n-hexane extracts had some degree of activity on the selected test microorganisms probably because it is a non-polar solvent. This was shown by the various zones of inhibition observed on the agar plates. Bacillus subtilis, leaf extract was $18.00 \pm 2.82 \mathrm{~mm}$ the stem extract was $4.50 \pm 2.21 \mathrm{~mm}$ and the bark extract was $4.50 \pm 2.12 \mathrm{~mm}$. Escherichia coli, leaf extract $18.00 \pm 4.24 \mathrm{~mm}$; stem extract $14.00 \pm 1.4 \mathrm{~mm}$ and bark extract $11.00 \pm 1.41 \mathrm{~mm}$. Staphylococcus aureus leaf extract, $23.50 \pm 2.12 \mathrm{~mm}$; stem extract $20.50 \pm 0.71 \mathrm{~mm}$ and bark extract $23.00 \pm 1.41$. Candida albicans, leaf extract $10.00 \pm 2.82$ stem extract $11.00 \pm 1.41$ and bark extract $8.50 \pm 0.70$. The zone of inhibition was used to determine the effectiveness of the plant extract in inhibiting the microorganism. The leaf extract showed the highest activity against the test micro organisms, but the the stem and bark extracts also had some some degree of activity. This finding is in consonance with that of [Harbon, 1998], who showed that Cola gigantea contains a variety of phytochemicals including alkaloids, flavonoids and tannins. Moreover, [Onyema and Ajiwe, 2014], reported that the results of the phytochemical analysis of Colagigantea leaves showed the presence of some secondary metabolites such as Alkaloids, Carbohydrates, Cardiac glycosides, flavonoids, steroids, tannin, terpenoids in various concentrations while cyanogenic glycosides and saponin were conspicuously absent. The values of Mineral elements; Cd $(0.40 \mathrm{mg} / \mathrm{g})$, As $(0.03 \mathrm{mg} / \mathrm{g}), \mathrm{Cr}(0.90 \mathrm{mg} / \mathrm{g}), \mathrm{Co}$ $(0.43 \mathrm{mg} / \mathrm{g}), \mathrm{Fe}(0.04 \mathrm{mg} / \mathrm{g})$ etc in the leaves all fell below the WHO recommendations thus showing its overall safety for therapeutic purposes. [Onyema and Ajiwe, 2014 also studied the antimicrobial analyses on eleven bacterial and three fungal species using the Punched Agar diffusion method with two isolated fractions with $\mathrm{R}_{\mathrm{f}}$ values of 0.4467 and 0.7067 for leaf fractions and compared with a standard drug cipromax fort (a broad spectrum antibiotic) and recorded average diameter zones of inhibition which ranged between $10 \mathrm{~mm}$ and $28 \mathrm{~mm}$.

The presence of high concentrations of flavonoid and steroids in the leaves confirms its medicinal value. In the stem and leaves, flavonoids, steroids and alkaloids are found in the highest concentration. The major constituent in the plant that shows most of the therapeutic properties is the flavonoids [Onyema and Ajiwe, 2014].

The activity of the n-hexane extracts may be due to the fact that the active substances in the leaf, stem and bark of the Colagigantea were non-polar in nature. This report is in contrast with the findings of [Agu et al., 2013], who showed that the ethanolic solutions (polar) of the tangerine seed extracts displayed broad spectrum activity with zones of inhibitions of $20 \mathrm{~mm}$ for Staphylococcus aureus, $15 \mathrm{~mm}$ for Escherichia coli. Bacillus subtilis showed the lowest sensitivity, this may be as a result of the fact that it is a spore-former, whereas Staphylococcus aureus and Candida albicans showed a great deal of sensitivity to the extracts.

\section{Conclusions}

The high amount of phytochemicals present in Cola gigantea makes it a suitable active ingredient for drug formulation and use for the treatment of diseases caused by the selected microorganisms used for this work. Since most microorganisms now develop resistance to most of the drugs presently used for treatment of infections they cause, Cola gigantea can now serve as a new remedy against them. More research work should be done to determine the active ingredients that possess these antimicrobial activities. The ingredient can then be extracted and used in producing new antimicrobial drugs. The plant should also be tested on other disease causing microorganisms for its potency on them. This would encourage its used in orthodox medicine.

\section{Acknowledgements}

We acknowledge the efforts of the entire Laboratory Staff of Microbiology and Biochemistry Departments of Nnamdi Azikiwe University, Awka for helping out with the preparation of the culture media for the Microbiological Analyses and the Instrumentation of the Biochemical Analyses respectively.

\section{REFERENCES}

[1] F. C. Tenover, 2006. Mechanisms of antimicrobial resistance in bacteria. American Journal of Medicine, 119 (6); S3 - S10.

[2] C.O. Frank, C.A. Kingsley, 2014. Proximate Composition, Physiological Changes during Storage, and Shelf Life of Some Nigerian Varieties of Yams (Dioscorea species). Journal of Scientific Research and Reports, 3 (4); 553-562.

[3] R.N. Okigbo, C.E. Enweremadu, K.C. Agu, R. CIrondi, B.C. Okeke, S.N. Awah, C.G. Anaukwu, I.O. Okafor, C.U. Ezenwa, A.C. Iloanusi, 2015. Control of white yam 
(Dioscorea rotundata) rot pathogen using peel extract of water yam (Dioscoreaalata). Advances in Applied Science Research, $6(10) ; 7-13$.

[4] P. Tiwari, B. Kumar, M. Kaur,, G. Kaur, H. Kaur, 2011. Phytochemical Screening and Extraction. International Pharmaceutical Sciencial, 1 (1); 1-19.

[5] F. R. Irvine, 1961. Woody Plants of Ghana, Oxford University Press, London, UK.

[6] M. A. Sonibare, M. O. Soladoye, O. O. Esan, O. O. Sonibare, 2009. Phytochemical and antimicrobial studies of four species of Cola Schott \& Endl. (Sterculiaceae). African Journal of Traditional, Complementary and Alternative Medicines, 6 (4); 518-525.

[7] L. T. Benjamin, A. M. Rogers, A. Rosenbaum, 1991. Coca-Cola, caffeine, and mental deficiency: Harry Hollingworth and the Chattanooga trial of 1911," Journal of the History of the Behavioral Sciences, 27 (1); 42-55.

[8] T. Odugbem, 2006. Outlines and Pictures of Medicinal Plants from Nigeria, Vol. 10, University of Lagos Press, Lagos, Nigeria.

[9] C. Muthu, M. Ayyanar, N. Raja, S. Ignacimuthu, 2006. Medicinal plants used by traditional healers in Kancheepuram District of Tamil Nadu, India. Journal of Ethnobiology and Ethnomedicine, 2 (43).

[10] Christian, A.K. George, V.E. Boamah, F. Adu, K.B. Mensah and L. Adu-Amoah, 2012. Antimicrobial and
Anti-Inflammatory Activities of Pterygota macrocarpa and Cola gigantea (Sterculiaceae). Evidence-Based Complement ary and Alternative Medicine, Article ID 902394, 2012; 1 - 9.

[11] J.B. Harbon, 1973. A Guide to Modern Techniques of Plant Analysis. Chapman and Hall, New York. 341-344.

[12] B.O. Obadoni, P.O. Ochuka 2001. Phytochemical Studies and Comparative Efficacy of the Crude Extract of Some Homeostatic Plants in Edo State and Delta State of Nigeria. Global Journal of Pure Applied Sciences, 8 (2); 203-208.

[13] D. Pearson, 1974. Chemical analysis of food, Churchill Livingstone. 8th Edition Pg. 5 - 63.

[14] J.B. Harbon, 1998. Phytochemical Methods. A Guide to Modern Techniques of Plant Analysis. Chapman Hall London. 3rd Edition, 270-280.

[15] C.T. Onyema, V.I.E. Ajiwe, 2014. Phytochemical and Antimicrobial Analysis of the Stem of Cola gigantea (Sterculiacea). Journal of Engineering and Science, 3 (4); 1 11 .

[16] K.C. Agu, C.A. Igweoha, C.N. Umeh, 2013. Antimicrobial Activity of the Ethanolic and Petroleum Ether Extracts of Tangerine Seed on Selected Bacteria. International Journal of Agriculture and Bioscience, 2 (1); 22-24.

[17] A. Wadood, M. Ghufran, S.B. Naeem, A. Khan, R. Ghaffar and Asnad, 2013. Phytochemical Analysis of Medicinal Plants Occurring in Local Area of Mardan. Biochem Anal Biochem, 2 (144), doi: 10.4172/2161-1009. 1000144. 